\title{
DIGITAL EDUCATION POLICIES IN ITALY: A RECOGNITION ON THE ACTIONS REALIZED
}

\author{
Alberto Fornasari \\ University of Bari Aldo Moro, Department of Sciences of Education, Psychology and Communication \\ Palazzo Chiaia Napolitano, via Scipione Crisanzio n.42, Bari, Italy
}

\begin{abstract}
This article covers in its first part the digital educational policies elaborated in Italy as part of the plan known as "Piano Nazionale Scuola Digitale" (PNSD). This plan constitutes in fact the orientation document issued by the "Ministero dell'Istruzione, dell'Università e della Ricerca" (MIUR) for the introduction of a comprehensive strategy of innovation for Italian schools, and a new placement of its educational system in the digital age. In the second part of the article, we report the data (extracted by "Osservatorio Tecnologico" of MIUR) concerning the condition of the digital school in Italy, through a survey of the actions undertaken and the criticalities encountered, deepening the theme of digital skills and media education.
\end{abstract}

\section{KEYWORDS}

Digital, Education, Policies, Italy, Good Practices, Competences

\section{INTRODUCTION}

For years now, there have been many enquiries about what kind of education should be promoted in the digital age, and what tools should be used to do that. The debate between experts in media education, media literacy, teachers and policy makers is intense and rich. An important premise is that to speak only about digitalization is no longer enough. That is because we risk to exclusively focusing our efforts on the technological dimension, rather than on the epistemological and cultural ones. The "Piano Nazionale Scuola Digitale" represents in Italy a basic component of Law 107/2015, an operational vision that reflects the position of the Italian Government in relation to the most important challenges of innovation of the public system: the core of this vision is the innovation of the school system and the opportunities offered by digital education. Therefore, it is not a simple application of technology: in fact, no educational step can be separated from an intensive interaction between teacher and student (as recently mentioned by OCSE) and technology cannot be distracted from this fundamental "human relationship", in which the individual is a core part. Therefore, PNSD answers the call for the establishment of a vision of Education in the digital age, through a process that, as far as schools are concerned, is related to the challenges that the whole society faces in the interpretation and support of lifelong learning (life-long) and in all contexts of life, formal and informal (life-wide). This is confirmed by the High Level Conference of the European Commission of December 2014, by several publications of the OCSE's Centre for Educational Research and Innovation, by the New Vision for Education Report of the World Economic Forum, and by research such as 'L'Educazione per il $21^{\circ}$ secolo" published by Ambrosetti Think Tank. It is, primarily, a cultural action, which starts from a renewed idea of school, intended as an open learning space and not merely a physical place, and as a platform that enables the students to develop their skills needed during their lives. In this paradigm, the technologies become enabling, daily, ordinary, at the service of the school activity, first and foremost the activities oriented to training and learning, as well as to the administration, contaminating - and, in fact, reuniting - all the school spaces: classrooms, common spaces, laboratories, individual spaces and informal spaces. With repercussions that spread throughout the territory. The objectives are the same as those in the educational system: the competences, the learning, the results of the students and the impact that they will have on the society as individuals, as citizens, and as professionals. These objectives will be updated in content and methods, in response to the challenges of a world that is rapidly changing, which requires more 
and more mental agility, transversal skills and an active role for young people. These objectives will be updated in content and methods, in response to the challenges of a world that is rapidly changing, which requires more and more mental agility, transversal skills and an active role for young people. This is why it is mandatory - and this represents the greatest cultural and human investment - for all school staff, and not only the teachers, to get involved, and be supported, in order to embrace the essential challenges of innovation: methodological-didactic challenges, for teachers, and organisational challenges, for school leaders and administrative staff. The tools to achieve them, or at least to follow their path, are contained in this Plan, and will probably not be limited to it. Defining the skills that students need is a much wider and more structured challenge than the one that the common feeling synthesizes in the critical use of the Web, or in IT. We need to address it starting with an idea of skills aligned to the twenty-first century: consisting in new literacy, but also, and especially, of transversal skills and attitudes to be developed. Specifically, there is also a need to strengthen skills relating to the understanding and production of complex and articulated contents, within the world of digital communication, where granularity and fragmentation sometimes take precedence. That is why it is essential that we work on information literacy and digital literacy, focusing on the role of information and data in the development of an interconnected society based on knowledge and information. It is in this context that we must consider the challenges represented by the relationship between public and private, the relationship between digital creativity and craftsmanship, and between digital entrepreneurship, manufacturing and work. It is also in this context that the introduction to logical and computational thinking and the familiarisation with the operational aspects of information technology should be placed. In this paradigm, students must be informed users of digital environments and tools, but also producers, creators, designers. And the teachers, on their side and in particular with regard to e-skills, will have to be placed in the right conditions, in order to be able to act as facilitators of innovative educational pathways, based on content that is more familiar to their students.

\section{POLICIES ABOUT DIGITAL EDUCATION IN ITALIAN SCHOOLS}

In 2007, for the first time in Italy, a National Plan for the Digital School was presented, with the main objective of modifying the learning environments and promoting digital innovation in the school (Table 1).

Table 1. Investments for Digital Environments in Schools

\begin{tabular}{lll}
\hline N. of schools involved & N. of realized projects & Amount invested \\
\hline 3.600 & 14.983 & $€ 494.000 .000,00$ \\
\hline
\end{tabular}

We will review the different actions taken by the MIUR on this matter. In 2008, for the first time, the "Azione LIM" - which promoted the widespread use of the Interactive Multimedia Whiteboard (LIM) in classroom teaching - was promoted. The interactive whiteboard was seen as an object with features that were similar to the slate board that was supposed to be used in the classroom, without spoiling them, and allowing teachers to acquaint themselves progressively with these technologies. With this action, 35,114 interactive whiteboards have been assigned and 72,357 teachers have been formed for both the technical and didactic use of the interactive whiteboard. Afterwards, "Action Cl@ssi 2.0" characterized by the slogan "no longer the classroom in the laboratory, but the laboratory in the classroom" had the aim of stimulating the design and implementation of innovative learning environments. The project involved, starting in 2009 and in the following 3 years, 416 classes of all levels on the purchase of technological equipment and for support and training. In 2010 "Azione Editoria digitale scolastica" focused on the production of digital content in 20 schools, across the various school orders and levels; in 2011 "Azione Scuol@ 2.0" allowed 14 schools to pursue a very advanced line of innovation, through strategies that combine innovation in educational planning to new models of human and infrastructural resources' organization of the school institution. In 2012 "Accordi MIUR - Regioni": in order to support the process of digital innovation in a more capillary way on the territory, the previous mentioned agreements "MIUR - Regioni" were created, to ensure greater synergy and collaboration between central and regional levels. These agreements, signed on 18 September 2012, made it possible to assign an additional 1,931 LIM, form 905 Cl@ ssi 2.0 and 23 Scuole 2.0. In the same year, the "Azione Centri Scolastici Digitali" (CSD) (Digital School Centres Action), was established in order to meet the needs of schools located in particularly disadvantaged areas from a geographical point of 
view (legislative decree 18 October 2012, n. 179), and allowed 45 initiatives to be implemented to support schools located on small islands or in mountain areas, equipping them with technological infrastructures and connecting them to schools in urban centres. In short, the 2008-2012 investment strategy aimed to bring the digital world into the classroom, to address a large number of students, regardless of the disciplines involved. In 2013 was launched "Azione wi-fi" for wireless connectivity in schools. Then was born "Azione Poli Formativi", through which some educational institutions have been identified for the organization and management of digital training courses for teachers (Table 2).

Table 2. Investments on Training of Teaching Staff on New Technologies

\begin{tabular}{|c|c|c|c|c|c|}
\hline Objective & Actions & $\begin{array}{l}\text { Amount eligible } \\
\text { for funding }\end{array}$ & $\begin{array}{l}\text { Realized } \\
\text { projects }\end{array}$ & $\begin{array}{l}\text { Schools reached } \\
\text { (average per y.) }\end{array}$ & $\begin{array}{l}\text { Teachers } \\
\text { involved }\end{array}$ \\
\hline \multirow{3}{*}{$\begin{array}{l}\text { To increase the } \\
\text { dissemination, } \\
\text { access and use of } \\
\text { information in } \\
\text { schools }\end{array}$} & $\begin{array}{l}\text { Training for teachers and } \\
\text { school staff on new } \\
\text { communication technologies }\end{array}$ & $€ 45.628 .737,81$ & 5.557 & 495 & 128.618 \\
\hline & $\begin{array}{l}\text { Initiatives for the development } \\
\text { of the information society } \\
\text { through multi-functional } \\
\text { service centers }\end{array}$ & $€ 5.483 .532,00$ & 218 & 495 & 15.078 \\
\hline & National Projects & $€ 7.072 .776,84$ & 8 & 495 & 147 \\
\hline
\end{tabular}

Specifically, following a special public notice, the schools involved (both as individuals and organized in a network) were invited to present their training projects, and the best ones were selected to play the role of the so-called "Training Poles" and, therefore, had the task of organizing and managing the teacher's training as described in the selected project. For the training activities, the Training Poles have employed teachers who are competent in the field, identified on the basis of provincial lists (selection of 2013) or regional lists (selection of 2014), prepared by the respective regional school offices, following the submission of voluntary applications by interested teachers. It is, in fact, an activity of peer training. 25,056 requests from teachers were registered, while 2,473 tutors, chosen from among teachers of all levels, were self-applicants as trainers. During the 2007-2013 programming period, Basic and Advanced Didatec projects were promoted, and about 480 schools were involved as headquarters/presidents of courses. For the Basic and Advanced Didatec projects, 20 teaching units were produced: 15 materials dedicated to kindergarten on the use of technologies for teaching and digital media education, plus 5 materials documenting experiences related to coding

\section{THE STATE OF THE ART OF THE DIGITAL SCHOOL IN ITALY}

There are 326,000 classrooms in over 33,000 "active" school buildings: $70 \%$ of them are connected to the network via wire or wireless (but usually with a connection that is not suitable for digital teaching), $41.9 \%$ are equipped with interactive whiteboards and $6.1 \%$ are equipped with interactive projectors. There is a total of 65,650 school laboratories, with an average of 7.8 per institute. Of these, $82.5 \%$ are wired or wirelessly connected to the network, $43.6 \%$ are equipped with interactive whiteboard and $16.9 \%$ with interactive projectors. A general estimation, summing up the endowments of classrooms, laboratories and school libraries, indicates in approximately 1,300,000 units the technological endowments available to the schools (605,000 in the laboratories, 650,000 in the classes and the remaining amount in the libraries). A summary of the technology/students ratio over the past year has shown a shift from a national average of 1 device for every 8.9 pupils to one of 7.9: although the figure does not allow qualitative interpretations, it is a demonstration that the penetration of the digital school is made concrete. These are the data contained in the Technological Observatory managed by MIUR and referred to the surveys of the school year 2014-2015. In 2000, the Technological Observatory was established as a telematic support service to collect data on the digitization process of schools. For that purpose, surveys were carried out periodically on the spread of new technologies in Italian educational institutions. In 2008, with the formalisation of the Interministerial Working Group for the Development of Scientific and Technological Culture, the survey took on a census importance, and focused on the state of scientific equipment and laboratories in schools. As a research 
methodology the surveys relating to the multimedia equipment of the didactics were conducted systematically and periodically by the MIUR. These are surveys to which the schools (state and equal) adhere voluntarily, but a very good response rate has always been recorded ( $97.6 \%$ for state schools and $54.1 \%$ for charter schools). The last analysis (in relation with the academic year 2014/2015) was divided into 3 main areas: dematerialisation of services (sites and portals, school-family communication, electronic class and teacher register, centralised management of educational multimedia contents); technological equipment of laboratories and libraries (connections, computers, interactive whiteboards and projectors); technological equipment of classrooms (connections, fixed and mobile devices supplied to students and teachers, interactive whiteboards and projectors). In analogy with the OCSE indicator that monitors the supply of PCs and other educational tools for students, the MIUR survey also offers a summarized data that attempts to measure the degree of digitization of educational institutions (also allowing a geographical comparison between different situations) comparing students and new technologies. As far as digital administration is concerned, the data from the 2014-2015 survey contained in the Technological Observatory showed a fairly good progress in the dematerialization and digitalization of the services of educational institutions. $99.3 \%$ of educational institutions have their own website, 58.3\% use forms of online school-family communication, $69.2 \%$ use a type of electronic class register (no accurate data is currently available for "class" dissemination), $73.6 \%$ use the teacher's electronic register and, lastly, $16.5 \%$ use forms of centralized management LMS (Learning Management Systems such as Moodle) for teaching and its contents. The administrative digitization of schools is instead a more difficult process: a recent study conducted by the MIUR shows a level of saturation of the paper archives of schools already at $80 \%$; in addition, $68 \%$ do not appear to have a document management computer system, and at least $80 \%$ do not have the one for substitute storage according to law. As far as digital identity is concerned, article 1, paragraph 28, of Law no. 107 of 2015 introduced the objective of associating a student's profile with a digital identity. So far, the main process through which the MIUR has associated a digital profile to students has been the Student Card, which is currently a personal card attesting to the status of student; it is associated with the student's access to an online area, that allows them to access different kinds of goods and services and to policies on the right of education. There are 2.7 million active "Student Cards" in circulation (and 8 million distributed over the years), on which have been activated 47,000 agreements with public and private partners, 3,000 of which of a national type. In addition, 1 million students are registered on the "IoStudio" portal, for 370.000 accesses per week. As far as digital content is concerned, the Database of textbook adoptions for the academic year 2015/2016 outlines a still rather limited scenario of digital adoptions. The three types of adoption (provided for by Ministerial Decree 781/2013), are divided as follows: in the second grade secondary, 35\% adopts mainly paper books with supplementary digital content, $63.9 \%$ also digital books and $1.1 \%$ only digital materials, while in the first grade secondary the percentages are respectively $33.2 \%, 66.1 \%, 0.7 \%$. The official figure for other formulas for the adoption and use of content, thus including self-production, on the other hand, is $2 \%$ for the second grade and $1 \%$ for the first grade. As far as student skills are concerned, Italy ranks 25th in Europe for the number of Internet users (59\%) and 23rd for basic digital skills (47\%). This gap is also visible in the case of specialist ICT skills (17th place) and in the number of graduates in Scientific or Technological disciplines (STEM), for which Italy ranks 22nd, with 13 citizens for every 1,000. As for the students, according to recent OCSE data, every fifteen-year-old Italian uses the computer in class 19 minutes a day, against an OCSE average of 25 minutes, with peaks in Greece (42 minutes) and Australia (52). The OECD-PISA tests, on the other hand, show adequate results with regard to problem-solving (510 compared to an OCSE average of 500), but are lacking in terms of skills in mathematics (485 compared to an average of 494) and science (494 compared to an average of 501). However, there was an average growth between 2002 and 2013 for the overall Italian result. As regards the relationship between digital entrepreneurship and work, the recent EU Commission Communication on "Digital Single Market" documents that the demand for workers with "adequate digital skills" is growing by $4 \%$ per year across Europe and could reach 825,000 uncovered jobs by 2020 if no concrete actions are developed. As far as teacher training is concerned, the data of the OCSE TALIS 2013 survey sees Italy in first place for ICT training needs of its teachers: at least 36\% stated that they were not sufficiently prepared for digital teaching, compared to an average of $17 \%$. Italy is also the leading OCSE country, with a distance from the others, for the percentage of teachers aged over 50 $62 \%$, compared to an OCSE average of $35 \%$ in secondary school (OECD, 2014). This data will improve with the recruitment provided by "La Buona Scuola" but it will remain remarkably high. The Digital Economy Index ranks Italy in 25th place out of 28, with structural weaknesses in connectivity and human capital. This subject has, on one side, a strong impact on the growth of the digital school, on the other side, has a great 
stimulation potential. In the last year, the (strictly) digital economy represented $2.54 \%$ of total employment in Italy, and 3.72\% of GDP (according to OCSE sources). The first data is substantially in line with the OECD average (2.85\%). Two key issues cause this: the process of digital school diffusion that in recent years has been rather slow, and actions often not incisive and not comprehensive, although in line with the objectives set at European level. The time has come to invest in an organic plan of innovation for Italian schools, with coherent programmes and actions that include access, learning environments, devices, platforms, digital administration, research, training and, of course, teaching, methodology and skills.

\subsection{The National Plan for Digital School (PNSD)}

The "Piano Nazionale Scuola Digitale" (PNSD) stipulates 27 actions to achieve the objectives listed: action \#1 - Ultra-wideband optical fibre for every school; action \#2 - Indoor cabling (LAN/W-Lan) for the entire school premises; action \#3 - Connectivity fee: the right to the Internet starts at school; action \#4 - Environments for integrated digital teaching; action \#5 - Challenge Prize for the digital school (Ideas' Box); action \#6 - BYOD (Bring Your Own Device) Active Policy Guidelines; action \#7 - Plan for practical learning Synergies - Innovative School Building; action \#8 - Unique Authentication System (Single-Sign-On); action \#9 - A digital profile for every student; action \#10 - A digital profile for every teacher; action \#11 - Administrative digitalization of the school; action \#12 - Electronic register; action \#13 - "School data" strategy; action \#14 - A common framework for students' e-skills; action \#15 - Innovative scenarios for the development of applied e-skills; action \#16 - A research unit for 21st century competencies; action \#17 - Bringing computational thinking to the whole primary school; action \#18 - Upgrade the "Technology" curriculum to the first grade secondary school; action \#19 - A curriculum for (digital) entrepreneurship; action \#20 - Girls in Tech \& Science; action \#21 - Digital Careers Plan Synergies - School-work alternation for digital enterprise; action \#22 - Minimum standards and interoperability of online learning environments; action \#23 - Promotion of Open Educational Resources (OER) and guidelines on self-production of educational content; action \#24 - School Libraries as literacy environments for the use of digital information resources; action \#25 - In-service training for educational and organisational innovation; action \#26 - Strengthening initial training on educational innovation; action \#27 - Technical assistance for first cycle schools Synergies - New training for new employees.

\section{DIGITAL COMPETENCES AND MEDIA EDUCATION OF STUDENTS}

Talking about digital competences involves a wider starting point: firstly, it means talking about competences, and then about didactic paths and pedagogical plans. If the objective of our educational system is to develop students' competences, instead of simply "transmitting" study programmes, then the role of competence-based teaching, enabled by digital competences, is fundamental as it activates cognitive processes, promotes relational dynamics and induces awareness. Skills are not taught, they are acquired, and the link between skills and new learning environments is undoubtedly strong. The educational model on which to work is the competence-based learning, meant as planning that focuses on transversality, sharing and co-creation, and as didactic action characterized by exploration, experience, reflection, self-evaluation, monitoring and evaluation. The first step is therefore to take advantage of the opportunities offered by digital technologies to address the skills developed during the course of the project. In this framework, digital technologies support all dimensions of transversal competences (cognitive, operational, relational, and metacognitive). But they also fit vertically, as part of the literacy of our time and fundamental skills for a full, active and informed citizenship, as anticipated by the Recommendation of the European Parliament and the Council of Europe and as even better emphasized by frameworks, such as 21st Century Skills (Skills for the 21st century), promoted by the World Economic Forum. The interpretation of what skills are useful and central in our time cannot be disconnected from the historical phase in which our students are growing up, and is thus constantly evolving. Frameworks, such as 21 st Century Skills, are therefore an important link between the general framework in which education operates - teaching and skills - and the need to express the role, both vertical and transversal, of digital skills. In this vision, digital is both Foundational Literacy (new basic literacy), with its important and growing verticality, and a crucial vector for the development of Competencies and Qualities. The e-skills vision echoes in the paradigm of media and media education, 
through early dimensions. Digital is, in fact, on the one hand a "conveyor belt", a characterized and unneutral media for developing and practicing skills and attitudes, within and through each discipline; a didactic for problems and projects. It is the "alphabets" of our time - at the centre of which lies computational thought - a new syntax, between logical and creative thought, forming the language that we increasingly speak today. It is, finally, at a higher level, acting as agent of the great social, economic and behavioural changes in the economy, law and architecture of information, and that results in "digital citizenship" skills, essential to tackle our time. With an emphasis on this last dimension, there are very interesting experiences of mapping and reconstruction of skills, such as the Web Literacy framework edited by the Mozilla Foundation and the effort made by Media Smarts on behalf of the Canadian Government. To further support the construction of a conceptual model, there are frameworks such as DIGICOMP (Ferrari, 2013), which identifies a list of 21 described competences for knowledge, skills and attitudes, included in 5 areas: Information, Communication, Content Creation, Security and Problem Solving. These frameworks are therefore useful for identifying the specific skills required, and in close contact with Information Literacy. The development of students' e-skills therefore requires, also in Italy, a dedicated strategy aimed to assist educational institutions in their didactic planning, starting from a first necessary orientation action, through the identification of a clear and shared framework. It is necessary to clarify what are and will be central contents for the students, enhancing their close link with the new learning environments and paradigms facilitated by ICTs.

\section{CONCLUSION}

According to the analysis of the article, an investment must be made in a sustainable vision of a digital school, not limited merely in placing technologies at the centre of the spaces, on the contrary enabling the new educational concepts to be developed and practiced by teachers and students, together with the technologies. The necessity of bringing laboratory teaching back to the centre is strongly felt, as an essential meeting point between knowledge and know-how. The core of this vision is the innovation of learning environments. Each school must have an enough number of environments and equipment allowing digital teaching, chosen and adapted to the needs of teachers and students as well to the contexts of their realization. To make sure that the classroom is no longer a physical limit but a place empowering and accessible, is required a package of investments, primarily, for the creation of "light" and flexible environments fully adapted to the use of digital. Secondly, in terms of policies, we need to overcome a fragmentary system in which the concentration of investment into certain schools, especially in "technology intensive environments", has failed to deliver the benefits of the system. The analyzes presented in the paper, which are the result of a personal reflection, contribute to provide specific information about Italian policies on digital education. Through careful monitoring of all the actions promoted in this field by the Italian government and the MIUR allows an international audience to know the good Italian practices activated.

\section{REFERENCES}

Baldascino, R., 2015. Insegnare ed apprendere in un mondo digitale. Tecnodid, Napoli.

Bonani, G.P., 2003. Formazione digitale. Progettare l'e-learning centrato sull'utente. FrancoAngeli, Milano.

Bruner, J.S., 2015. La cultura dell'educazione. Nuovi orizzonti per la scuola. Translated by L. Cornalba. Feltrinelli, Milano.

Buckingham, D., 2006. Media education. Alfabetizzazione, apprendimento e cultura contemporanea. Translated by L. Di Nitto. Erickson, Trento.

Buckingham, D., 2013, Media literacy per crescere nella cultura digitale. Armando Editore, Roma.

De Kerckhove, D. 2009. Dall'alfabeto a internet. L'homme «littéré»: alfabetizzazione, cultura, tecnologia. Translated by A. Caronia. Mimesis, Milano-Udine.

Faggioli, M. (ed), 2010. Tecnologie per la didattica. Apogeo Education, Milano.

Felini, D. and Trinchero, R. (eds), 2015. Progettare la media education. Dall'idea all'azione, nella scuola e nei servizi educativi. FrancoAngeli, Milano.

Ferrari, A., 2013. DIGCOMP: A Framework for Developing and Understanding Digital Competence in Europe. Publications Office of the European Union, Luxembourg. 
Galliani, L., et al, 1999. Ambienti multimediali di apprendimento. Pensa Multimedia, Lecce.

Garavaglia, A., 2011. Didattica on line. Dai modelli alle tecniche. Unicopli, Milano.

Jenkins, H., 2010. Culture partecipative e competenze digitali. Media education per il XXI secolo. Guerini studio, Milano.

Limone, P. (ed), 2008. Nuovi media e formazione. Armando Editore, Roma.

Limone, P., 2012. Ambienti di apprendimento e progettazione didattica. Proposte per un sistema educativo transmediale. Carocci, Roma.

Midoro, V. (ed), 2016. La scuola ai tempi del digitale. Istruzioni per costruire una scuola nuova. FrancoAngeli, Milano.

Molina, A. and Mannino, M., 2016. Educazione per la vita e inclusione digitale. Strategie innovative per la scuola e la formazione degli adulti. Erickson, Trento.

OECD, 2014. Education at a Glance 2014: OECD Indicators. OECD Publishing, Paris, https://doi.org/10.1787/ eag-2014-en.

OECD, 2018. Education at a Glance 2018: OECD Indicators. OECD Publishing, Paris, https://doi.org/10.1787/ eag-2018-en.

Prensky, M., 2010. Teaching Digital Natives: Partnering for Real Learning. Corwin, Thousand Oaks, California.

Prensky, M., 2013. La mente aumentata. Dai nativi digitali alla saggezza digitale. Erickson, Trento.

Rivoltella, P.C., 2017. Media education. Idea, metodo, ricerca. La Scuola, Brescia.

Rivoltella, P.C., 2017. Tecnologie di comunità. La Scuola, Brescia.

Roncaglia, G., 2018. L'età della frammentazione. Cultura del libro e scuola digitale. Laterza, Bari-Roma.

Trilling, B. and Fadel, C., 2009. 21 st Century Skills: Learning for Life in Our Times. Jossey-Bass, San Francisco.

Trinchero, R., 2006. Valutare l'apprendimento nell'e-learning. Dalle abilità alle competenze. Erickson, Trento.

Turkle, S., 2016. La conversazione necessaria. La forza del dialogo nell'era digitale. Translated by L. Giacone. Einaudi, Torino.

http://www.istruzione.it/allegati/2014/TALIS_Guida_lettura_con_Focus_ITALIA.pdf

https://www.ambrosetti.eu/ricerche-e-presentazioni/educazione-per-il-rilancio-e-competitivita-italia

http://www.istruzione.it/scuola_digitale/index.shtml

http://www.istruzione.it/allegati/2017/La_Buona_Scuola_Approfondimenti.pdf

http://www.cremit.it/il-nuovo-mooc-sulleducazione-digitale/

http://www.miur.gov.it/ricerca?p_p_id=101\&p_p_lifecycle=0\&p_p_state=maximized\&p_p_mode=view\&p_p_col_id=co lumn1\&p_p_col_count=1\&_101_struts_action=\%2Fasset_publisher\%2Fview_content \&_101_assetEntryId=1381180 \&_101_type $=$ content\&_101_urlTitle $=$ osservatoriotecnologico\&inheritRedirect $=$ true

http://www.cremit.it/educazione-civica-digitale-a-partire-dal-nuovo-sillabo-del-miur-e-conclusione-del-percorsocurricolo-e-cittadinanza

http://dati.istruzione.it/opendata/esploraidati/?pk_vid=f1058070141a965a154664939424d3e8

http://dati.istruzione.it/opendata/approfondimenti/statistiche/?catalogo=Istruzione

http://www.indire.it/progetto/didatec/

http://www.battelleforkids.org/networks/p21

http://www.oecd.org/education/ceri/

http://www3.weforum.org/docs/WEFUSA_NewVisionforEducation_Report2015.pdf 